\section{Sex inequalities in HIV-related practices in the Brazilian population aged 15 to 64 years old, 2008}

\author{
Desigualdades por sexo nas práticas relacionadas à \\ infecção pelo HIV na população brasileira de \\ 15 a 64 anos, 2008
}

\author{
1 Departamento de DST, AIDS \\ e Hepatites Virais, Ministério \\ da Saúde, Brasília, Brasil. \\ 2 Instituto de Comunicação \\ e Informação Científica \\ e Tecnológica em Saúde, \\ Fundação Oswaldo Cruz, \\ Rio de Janeiro, Brasil. \\ Correspondence \\ A. R. P. Pascom \\ Departamento de DST, AIDS \\ e Hepatites Virais, Ministério \\ da Saúde. \\ SQN 213, bloco I, apto. 611, \\ Brasília, DF 70872-090, Brasil. \\ ana.roberta@aids.gov.br
}

\section{Abstract}

The objective of this study is to analyze gender differences in HIV-related practices in the Brazilian population. A national survey was carried out in 2008 with a sample size of 8,000 individuals aged 15-64 years old. The sampling was stratified by macro geographical region and urban/rural areas. Logistic regression models were used to investigate the main predictors of consistent condom use. The results showed that women have less sexy, start sexual life later than men, have fewer casual sexual partners, but use condom less frequently than men. On the other hand, the coverage of HIV testing is significantly greater among women. Significant differences by gender were seen in all HIV-related risky practices. The greater vulnerability was always associated with women, with exception of HIV testing. The low proportion of condom use in infidelity situations was a problem for box sexes and deserves special consideration when developing prevention strategies.

Sexual Behavior; AIDS Serodiagnosis; HIV Infections; Sex Characteristics
Ana Roberta Pati Pascom 1

Célia Landmann Szwarcwald 2

\section{Introduction}

By the late 1980s and early 1990s, the number of AIDS cases among women increased in Brazil 1. During this period of the epidemic, there was an increased incidence among injecting drug users (IDU) and a high proportion of cases attributed to heterosexual transmission among men and women ${ }^{2}$. By the mid-90s, there was a sharp increase in AIDS incidence among women ${ }^{3}$, with the gender ratio ranging from 6.8 men per woman in 1990 to 1.6 in 20074.

Due to the growing number of female AIDS cases in Brazil, interventions targeting women were focused on transmission and prevention of HIV infection 5. Among female sex workers, selfempowerment and self-esteem were promoted for the adoption of HIV-preventive measures 6 .

Studies involving the monitoring of sexual risk behavior in the population have been recognized as important tools for controlling the spread of HIV/AIDS. A population-based response is essential to support new preventive measures and to propose effective strategies $?$.

In the 1990s, few initiatives to monitoring risk behaviors associated with HIV infection were undertaken in Brazil. We highlight the studies that have been performed with Brazilian Army conscripts since 1996 8,9; the Demography and Health Survey (DHS) performed in 1996 10; and the studies performed by the Brazilian Center for Analysis and Planning, in 1998 and 200511. 
Continuing the development of research on population-based behavior in 2004 and 2008, the Department of STD, AIDS and Viral Hepatitis of the Brazilian Ministry of Health conducted a national survey to investigate the Knowledge, Attitudes, and Practices (KAP) related to HIV infection and other STI (sexually transmitted infections) among individuals aged 15-64 in Brazil. The implementation of the survey provided an opportunity to develop indicators for the monitoring of preventive measures and strategies, and risk practices related to sexually transmitted infections in Brazil 12.

To understand gender differences with respect to practices related to HIV infection among individuals aged 15-64, we analyzed data from the KAP survey conducted in 2008.

\section{Methodology}

In 2008, nationwide survey was performed with a sample size of 8,000 people aged 15-64.

The sample was stratified by geographic macro-region (North, Northeast, Southeast, South and Central) and by type of area (urban, rural). In each of ten strata, the sample was conducted in three stages: at the census tract, household and individual level. In the first stage, census tracts were randomly selected with probability proportional to size. Within each census tract, eight households were systematically chosen from a randomly selected point and definition of the route. In each household, a list consisting of age, gender, and cohabitation of the residents was created. In each stratum consisting of cohabitation (live with or without partner), age (15-24, 25-34, $35-49,50-64)$ and gender only one respondent was selected for an interview with equiprobability. The number of individuals within each stratum formed by overlapping all three variables was established by allocation proportional to the square root of the number of inhabitants in each stratum 13 .

The project was approved by of the Ethics Committee, at Oswaldo Cruz Foundation ( $\mathrm{n}^{\circ}$. 243/04).

The 2008 KAP survey instrument included the following sections: socio-demographic conditions, knowledge on the transmission of HIV and other STI, STI prevention and control, HIV testing, licit and illicit drug use, and sexual practice.

The interviewers used Personal Digital Assistants (PDA) to complete the questionnaire. All responses were automatically converted into a database. As some questions were sensitive in nature and could cause embarrassment, denial or discomfort among respondents, sections re- lating to drug use and sexual practices were selfreported on the PDA itself, with optional use of headset among individuals with low education.

In this article, results on HIV test coverage and sexual practices related to the HIV infection are presented. The focus was given to the comparison of indicators for gender and age group in years (15-24, 25-34, 35-49, 50-64).

Indicators for sexual behavior included percentage of sexually active individual in life and in the past 12 months; percentage of individual who had onset of sexual activity before the age of 15; percentage of individuals having more than five casual partners over the last year; percentage of individuals having sexual intercourse with a steady partner, with casual partner, with paid partner (paid money to have sex), with paying partner (received money to have sex) and with a partner they met via the internet. Extramarital sex was defined as an individual reporting a casual partner in the last 12 months while living with a partner.

As for protected sex practices the following indicators were considered: the percentage of individuals who reported using male condoms at last sexual encounter in the past 12 months, with any type of partner and casual partner; and percentage of individuals reporting consistent condom use (use of condom in all sexual relations in the past 12 months), with a steady partner, with a casual partner and with any type of partner, as well as according to the extramarital sex situation.

The coverage of HIV testing among the sexually active population was measured by the percentage of sexually active individuals who reported having been tested for HIV at least once in lifetime.

For statistical analysis, data were calibrated according to the census distribution by region, urban-rural status, gender, age group, cohabiting status and education level. All statistic analyses were conducted using SPSS, version 17 (SPSS Inc., Chicago, USA), which takes into consideration complex sample survey features 14 .

For comparison of indicators by sex, we conducted statistical tests for differences between proportions $\left(\chi^{2}\right)$.

In order to investigate the main factors associated with protected sex practices, we performed a multivariate logistic regression to test predictors of, consistent condom use with any partner. A stepwise regression was performed 15 , based on maximizing statistical likelihood at each step, and significance levels of 5 and $10 \%$, respectively, for inclusion and exclusion of variables. The following covariates were investigated: age; gender; education (incomplete primary education; complete primary education and incomplete basic 
education; complete basic education and more); cohabiting status (living with a partner vs. no); skin color or race (white; black; brown; other); socio-economic status criteria defined by the Brazilian Association of Survey Enterprises 16; household income and individual income (no income; up to one minimum wage; 1-2 minimum wages; 2-5 minimum wages; 5-10 minimum wages; more than 10 minimum wages); receipt of free condoms in the last 12 months (yes; no); more than five casual partners in the last 12 months (yes; no); sexual intercourse before 15 (yes; no); illicit drug use (cocaine, marijuana or crack) ever (yes; no); extramarial intercourse during the last year - subset of respondents reporting casual partners (yes; no).

\section{Results}

Table 1 shows behavior and sexual practices of respondents aged 15 to 64 . For all age groups, sexual activity in the 12 months prior to the survey is higher among men, with the highest gender difference observed among older subjects, in whom $54.2 \%$ of women reported at least one sexual encounter in the last 12 months. In terms of first sexual intercourse before age 15, men become sexually active earlier than women, with the smallest gender difference seen in the younger age group.

Regarding the types of partner, the proportion of men with casual partners is about to times higher than of women, regardless of age group. The proportion of sexually active men who reported at least five casual partners in the last 12 months was three times greater than the proportion observed among women $(13.2 \%$ and $4.1 \%$, respectively). For both sexes, younger the age, the greater proportion of respondents with at least five casual partners in the last year (Table 1).

There are no significant differences by gender in the proportion of individuals that had sexual relations with paying partners for any age group. However, sexual relations with paid partners are more frequent among men $(\mathrm{p}<0.001)$ as well as partners they met via the Internet $(\mathrm{p}<0.001)$. The proportion of individuals reporting having paid partners and partners that they met on the internet is nearly eight times greater among men than women; and, the proportion of individuals that reported having partners they met on the Internet is nearly three times greater (Table 1).

Regarding the practices of protected sex, men use condoms in a greater proportion than women, and, in general, condom use decreases as age increases (Table 2). Condom use at last sex encounter was $65 \%$ among males aged 15 to 24 , and approximately $77 \%$ at last sex encounter with a casual partner. Among women, in the same age group, condom use at last sex was significantly lower, $44 \%$ at last sexual relation and $50 \%$ at last sexual relation with casual partner.

When comparing consistent condom use by type of partner, the largest gender difference among young people aged 15 to 24 was observed with casual partners: $57.4 \%$ for men and $33.6 \%$ for women.

The HIV test coverage for the sexually active population is greater among women than men at all age groups, with the largest difference seen among 15 to 24 year olds (Table 3). The coverage for the Brazilian population aged 15 to 64 was estimated at $36.5 \%$, with $45.6 \%$ among women and $27.2 \%$ among men.

The results presented on Table 4 show that approximately $21 \%$ of men and $11 \%$ of women had extramarital intercourse (i.e. reported living with a partner and having at least one casual sexual partner in the past 12 months). In relation to protected sex, the use of condom (at last sex and all sexual encounters in the past 12 months) with casual partners was significantly greater among those who did not live with a partner when compared with those who lived with a partner, for both genders $(\mathrm{p}<0.001)$.

On Table 5, we present the results of a multivariate logistic regression model investigating predictors consistent condom use with any partner. These included the analysis of the crude odds ratio (OR) included as predictors: being male; having received free condoms at least once in lifetime; not living with a partner; however having extramarital intercourse presented a negative association with consistent condom use.

The analysis of the adjusted OR estimated in the multivariate model also presented on Table 5 shows that the associations between consistent condom use and being male $(\mathrm{OR}=1.36$, $\mathrm{p}<0.001)$; living without a partner $(\mathrm{OR}=2.54$, $\mathrm{p}<0.001$ ); having received free condoms in the past 12 months before the survey $(\mathrm{OR}=1.78$, $\mathrm{p}<0.001)$. Conversely, having used illicit drugs at least once in lifetime (OR $=0.63, \mathrm{p}<0.001$ ) was negatively associated with the outcome.

\section{Discussion}

The results presented here show great gender differences with practices related to HIV infection.

In terms of sexual behavior, women have lower sexual activity, start their sex life later and have fewer casual partners and more steady partners than men, but use fewer condoms in all situations. More specifically, the multivariate 
Table 1

Percentage of individuals aged 15 to 64 , according to indicators of sexual behavior and sexual activities by age and gender. Brazil, 2008.

\begin{tabular}{|c|c|c|c|c|c|c|}
\hline \multirow{2}{*}{$\begin{array}{l}\text { Population } \\
\text { subgroup }\end{array}$} & \multirow[t]{2}{*}{ Indicators } & \multirow[t]{2}{*}{ Age (years) } & \multicolumn{2}{|c|}{ Gender } & \multirow[t]{2}{*}{ Total } & \multirow[t]{2}{*}{$\mathrm{p}$-value } \\
\hline & & & Male & Female & & \\
\hline \multirow[t]{10}{*}{ Total population } & Sexually active & $15-24$ & 81.8 & 73.5 & 77.6 & 0.001 \\
\hline & in life & $25-34$ & 95.7 & 96.7 & 96.2 & 0.407 \\
\hline & & $35-49$ & 95.6 & 97.8 & 96.7 & 0.036 \\
\hline & & $50-64$ & 94.6 & 95.8 & 95.2 & 0.410 \\
\hline & & Total & 91.1 & 89.8 & 90.4 & 0.222 \\
\hline & Sexually active in & $15-24$ & 69.7 & 64.8 & 67.2 & 0.057 \\
\hline & the last 12 months & $25-34$ & 88.6 & 87.6 & 88.1 & 0.579 \\
\hline & & 3549 & 87.7 & 82.3 & 84.9 & 0.006 \\
\hline & & $50-64$ & 79.6 & 54.2 & 66.3 & $<0.001$ \\
\hline & & Total & 81.0 & 73.7 & 77.3 & $<0.001$ \\
\hline \multirow{5}{*}{$\begin{array}{l}\text { Sexually active } \\
\text { population }\end{array}$} & Onset of sexual & $15-24$ & 40.8 & 29.4 & 35.4 & $<0.001$ \\
\hline & activity before the & $25-34$ & 39.0 & 17.5 & 28.0 & $<0.001$ \\
\hline & age of 15 & $35-49$ & 33.7 & 10.9 & 21.8 & $<0.001$ \\
\hline & & $50-64$ & 32.5 & 9.7 & 20.5 & $<0.001$ \\
\hline & & Total & 36.9 & 17.0 & 26.8 & $<0.001$ \\
\hline \multirow{30}{*}{$\begin{array}{l}\text { Sexually active } \\
\text { population in the } \\
\text { past } 12 \text { months }\end{array}$} & More than five & $15-24$ & 22.1 & 6.6 & 14.6 & $<0.001$ \\
\hline & casual partners in & $25-34$ & 12.3 & 3.9 & 8.0 & $<0.001$ \\
\hline & the last 12 months & $35-49$ & 9.8 & 3.1 & 6.5 & $<0.001$ \\
\hline & & $50-64$ & 6.1 & 1.6 & 4.2 & 0.002 \\
\hline & & Total & 13.2 & 4.1 & 8.8 & $<0.001$ \\
\hline & Sexual encounter & $15-24$ & 79.4 & 87.2 & 83.2 & 0.003 \\
\hline & with a steady & $25-34$ & 89.1 & 90.4 & 89.7 & 0.468 \\
\hline & partner in the last & $35-49$ & 83.9 & 90.4 & 87.1 & 0.001 \\
\hline & 12 months & $50-64$ & 84.7 & 85.3 & 85.0 & 0.823 \\
\hline & & Total & 84.2 & 89.0 & 86.5 & $<0.001$ \\
\hline & Sexual encounter & $15-24$ & 56.2 & 29.8 & 43.5 & $<0.001$ \\
\hline & with casual partner & $25-34$ & 35.3 & 19.3 & 27.2 & $<0.001$ \\
\hline & in the last 12 & $35-49$ & 29.1 & 12.1 & 20.6 & $<0.001$ \\
\hline & months & $50-64$ & 20.6 & 9.2 & 15.8 & $<0.001$ \\
\hline & & Total & 36.8 & 18.5 & 27.9 & $<0.001$ \\
\hline & Sexual encounter & $15-24$ & 2.7 & 2.4 & 2.6 & 0.757 \\
\hline & with paying partner & $25-34$ & 1.9 & 1.1 & 1.5 & 0.265 \\
\hline & received money for & $35-49$ & 1.3 & 1.4 & 1.3 & 0.887 \\
\hline & sex in the last 12 & $50-64$ & 0.8 & 1.0 & 0.9 & 0.715 \\
\hline & months & Total & 1.8 & 1.5 & 1.7 & 0.678 \\
\hline & Sexual encounter & $15-24$ & 6.0 & 0.8 & 3.5 & 0.001 \\
\hline & with a paying & $25-34$ & 7.0 & 0.6 & 3.8 & $<0.001$ \\
\hline & partner (paid & $35-49$ & 6.9 & 1.0 & 3.9 & $<0.001$ \\
\hline & money for sex) in & $50-64$ & 5.1 & 0.7 & 3.2 & 0.003 \\
\hline & the last 12 months & Total & 6.4 & 0.8 & 3.7 & $<0.001$ \\
\hline & Sexual encounter & $15-24$ & 10.3 & 2.6 & 6.5 & $<0.001$ \\
\hline & with a partner & $25-34$ & 4.5 & 1.2 & 2.8 & $<0.001$ \\
\hline & met through the & $35-49$ & 0.9 & 1.6 & 1.2 & 0.151 \\
\hline & internet in the last & $50-64$ & 0.3 & 0.3 & 0.3 & 0.929 \\
\hline & 12 months & Total & 4.3 & 1.6 & 3.0 & $<0.001$ \\
\hline
\end{tabular}


Percentage of individuals aged 15 to 64, according to indicators of condom use by age and gender. Brazil, 2008.

\begin{tabular}{|c|c|c|c|c|c|c|}
\hline \multirow{2}{*}{$\begin{array}{l}\text { Population } \\
\text { subgroup }\end{array}$} & \multirow[t]{2}{*}{ Condom use } & \multirow[t]{2}{*}{ Age (years) } & \multicolumn{2}{|c|}{ Gender } & \multirow[t]{2}{*}{ Total } & \multirow[t]{2}{*}{$\mathrm{p}$-value } \\
\hline & & & Male & Female & & \\
\hline Sexually active & During the last & $15-24$ & 65.1 & 44.0 & 55.0 & $<0.001$ \\
\hline population in the & sexual encounter in & $25-34$ & 37.7 & 28.2 & 32.9 & $<0.001$ \\
\hline \multirow[t]{3}{*}{ past 12 months } & the past 12 months & $35-49$ & 31.2 & 24.7 & 28.0 & 0.010 \\
\hline & & $50-64$ & 17.8 & 14.5 & 16.4 & 0.227 \\
\hline & & Total & 40.2 & 29.7 & 35.1 & $<0.001$ \\
\hline Sexually active & During the sexual & $15-24$ & 76.8 & 49.7 & 67.8 & $<0.001$ \\
\hline population in the & encounter with a & $25-34$ & 61.3 & 43.1 & 54.8 & 0.001 \\
\hline past 12 months, & casual partner in & $35-49$ & 58.3 & 44.0 & 54.1 & 0.030 \\
\hline \multirow[t]{2}{*}{ with casual partner } & the last 12 months & $50-64$ & 39.4 & 33.3 & 37.9 & 0.527 \\
\hline & & Total & 65.1 & 45.5 & 58.8 & $<0.001$ \\
\hline Sexually active & In all the sexual & $15-24$ & 41.3 & 27.9 & 34.8 & $<0.001$ \\
\hline population in the & encounters in the & $25-34$ & 23.0 & 20.3 & 21.6 & 0.269 \\
\hline \multirow[t]{3}{*}{ past 12 months } & last 12 months with & $35-49$ & 24.8 & 21.3 & 23.0 & 0.156 \\
\hline & any type of partner & $50-64$ & 21.4 & 19.4 & 20.5 & 0.482 \\
\hline & & Total & 28.3 & 22.5 & 25.5 & $<0.001$ \\
\hline Sexually active & In all the sexual & $15-24$ & 36.4 & 25.1 & 30.7 & 0.001 \\
\hline population in the & encounters in the & $25-34$ & 18.0 & 14.7 & 16.3 & 0.130 \\
\hline past 12 months, & last 12 months with & $35-49$ & 17.2 & 16.4 & 16.8 & 0.743 \\
\hline \multirow[t]{2}{*}{ with steady partner } & a steady partner & $50-64$ & 11.3 & 8.4 & 10.0 & 0.207 \\
\hline & & Total & 21.5 & 17.3 & 19.4 & 0.003 \\
\hline Sexually active & In all the sexual & $15-24$ & 57.4 & 33.6 & 49.6 & $<0.001$ \\
\hline population in the & encounters in the & $25-34$ & 48.1 & 35.4 & 43.6 & 0.016 \\
\hline past 12 months, & last 12 months with & $35-49$ & 49.1 & 37.6 & 45.7 & 0.079 \\
\hline \multirow[t]{2}{*}{ with casual partner } & a casual partner & $50-64$ & 34.0 & 25.9 & 32.0 & 0.392 \\
\hline & & Total & 51.0 & 34.6 & 45.7 & $<0.001$ \\
\hline
\end{tabular}

statistical model showed significant differences per gender in safe sex practices. Yet, controlled by other variables such as cohabiting status, being a male was a factor positively associated with consistent condom use with any type of partner. Similar gender differences were found in other surveys conducted in Brazil 17,18,19, and also in surveys performed in other countries 20,21,22,23.

The gender differences described in this study may be partially explained by gender issues, including the different demeanors and practices related to the sexuality of men and women $24,25,26,27$. Gender differences in the power of decision-making over preventive measures reflect the social role performed by women and the imbalance of power centered in men 28 . Poor preventive measures reflect the social role performed by women in the imbalance of power centered in men 28. In particular, the lack of power by women in the negotiation of condoms use does not favor its use among the female population 29 .
Even in situations where theoretically the control for protected sex is under the power of women, such is the case of female condoms, the adoption of preventive measures is still not frequent. The results of the present survey showed that $84 \%$ of women are aware of the female condom, but only $8 \%$ of women reported having used it once in their lifetimes. These findings corroborate other surveys, showing that despite the acceptability of the female condom, its use is still low ${ }^{30}$. One of the factors that may be influencing the low use of the female condom in Brazil is its high cost when compared to the male condom. The evaluation of strategies for introducing the female condom in some countries found some factors that may increase its use, such as training women how to use it, identifying the priority groups, and ensuring regular supply through distribution in public and private sectors 31 .

Besides the greater frequency of unprotected sex among women another relevant aspect is the 
Table 3

Coverage of HIV testing in sexually active population aging 15 to 64 years by gender and age. Brazil, 2008.

\begin{tabular}{lcccc}
\hline Age (in years) & Gender & Total & p-value \\
& Male & Female & & \\
\hline $15-24$ & 16.1 & 45.7 & 30.1 & $<0.001$ \\
$25-34$ & 36.4 & 65.1 & 51.0 & $<0.001$ \\
$35-49$ & 32.4 & 42.7 & 37.7 & $<0.001$ \\
$50-64$ & 22.4 & 21.6 & 21.9 & 0.753 \\
Total & 27.2 & 45.6 & 36.5 & $<0.001$ \\
\hline
\end{tabular}

Table 4

Proportion (\%) of individuals sexually active in the last 12 months according to cohabitation, sexual encounters with casual partner and condom use with casual partner by gender. Brazil, 2008.

\begin{tabular}{|c|c|c|c|c|c|c|}
\hline \multirow{2}{*}{$\begin{array}{l}\text { Population } \\
\text { subgroup }\end{array}$} & \multirow[t]{2}{*}{ Indicator } & \multirow{2}{*}{$\begin{array}{l}\text { Lives with } \\
\text { partner }\end{array}$} & \multicolumn{2}{|c|}{ Gender } & \multirow[t]{2}{*}{ Total } & \multirow[t]{2}{*}{ p-value } \\
\hline & & & Male & Female & & \\
\hline Sexually active & Had casual & Yes & 21.3 & 10.9 & 16.1 & $<0.001$ \\
\hline in the past 12 & partner in the & No & 63.4 & 35.0 & 50.7 & $<0.001$ \\
\hline months & last 12 months & $\mathrm{p}$-value & $<0.001$ & $<0.001$ & $<0.001$ & - \\
\hline Sexually active & Condom use & Yes & 50.9 & 32.2 & 44.5 & $<0.001$ \\
\hline during the last & during the & No & 73.3 & 54.6 & 67.5 & $<0.001$ \\
\hline $\begin{array}{l}12 \text { months } \\
\text { and had casual }\end{array}$ & $\begin{array}{l}\text { last casual } \\
\text { relationship }\end{array}$ & $\mathrm{p}$-value & $<0.001$ & $<0.001$ & $<0.001$ & - \\
\hline \multirow[t]{3}{*}{ partner } & Consistent & Yes & 43.2 & 25.3 & 37.1 & $<0.001$ \\
\hline & condom use & No & 55.5 & 40.8 & 51.0 & $<0.001$ \\
\hline & $\begin{array}{l}\text { with casual } \\
\text { partner }\end{array}$ & $\mathrm{p}$-value & 0.002 & 0.005 & $<0.001$ & - \\
\hline
\end{tabular}

biological disadvantage of women regarding HIV infection. Due to the physiology of the female sexual organ, women have twice the biological risk of being infected by HIV than men in unprotected heterosexual relations 24,32 .

A particularly interesting finding was the use of Internet to search for sex partners among men. One in 10 young men aged 15 to 24 had at least one sexual partner identified through the Internet. This new form of social network has been the target of international research 33,34,35,36. Among women, this practice is not frequent yet.

Regarding unprotected extramarital sex both men and women presented similar behavior. In the situation of extramarital sex, the use of condoms was low for both men and women. Once consistent condom use with a steady partner is not frequent, unprotected sex with casual part- ners increases the potential risks of STI among couples.

Regarding already HIV infected individuals, it is important to find out their serological status to avoid spread of the disease. The early detection of HIV infection not only reduces the viral transmission, but it also increases the quality of life of the infected patient 37 . The present survey suggests that the strategies to motivate HIV testing among the Brazilian population, with free tests through the public health network and the introduction of the HIV test in prenatal care have both shown positive results. The test coverage for the sexually active population in Brazil aged 15 to 64 was nearly $37 \%$, similar to the one observed in the United States 38 . However, relevant differences are found by gender, with the HIV test coverage among men over half of that of women. The difference is re- 
Results of the simple logistic regression and multivariate models with the regular use of condom with any partner in the last 12 months as outcome. Brazil, 2008.

\begin{tabular}{|c|c|c|c|c|c|c|}
\hline \multirow[t]{2}{*}{ Factors } & \multicolumn{3}{|c|}{ Univariate analysis } & \multicolumn{3}{|c|}{ Multivariate analysis } \\
\hline & OR * & $95 \% \mathrm{Cl}$ & p-value & OR * & $95 \% \mathrm{Cl}$ & p-value \\
\hline \multicolumn{7}{|l|}{ Gender } \\
\hline Male & 1.36 & $1.17-1.57$ & $<0.001$ & 1.36 & $1.16-1.59$ & $<0.001$ \\
\hline Female & 1.00 & - & - & 1.00 & - & - \\
\hline \multicolumn{7}{|c|}{ Lives with partner } \\
\hline Yes & 1.00 & - & - & 1.00 & - & - \\
\hline No & 2.69 & $2.32-3.13$ & $<0.001$ & 2.54 & $2.15-3.01$ & $<0.001$ \\
\hline \multicolumn{7}{|c|}{ Has already taken condoms for free } \\
\hline Yes & 1.98 & $1.70-2.31$ & $<0.001$ & 1.78 & $1.50-2.10$ & $<0.001$ \\
\hline No & 1.00 & - & & 1.00 & - & - \\
\hline \multicolumn{7}{|c|}{ Drug use ever } \\
\hline Yes & 0.84 & $0.68-1.05$ & 0.117 & 0.63 & $0.50-0.81$ & $<0.001$ \\
\hline No & 1.00 & - & - & 1.00 & - & - \\
\hline \multicolumn{7}{|c|}{ Live with partner and have had casual partner } \\
\hline Yes & 0.57 & $0.43-0.75$ & $<0.001$ & 0.79 & $0.58-1.07$ & 0.124 \\
\hline No & 1.00 & - & - & 1.00 & - & - \\
\hline
\end{tabular}

* OR (odds ratio) significantly different from 1 at a significance level of $5 \%$ (95\%Cl).

lated to the HIV testing during pregnancy: about $60 \%$ of sexually active women reported taking the HIV test during prenatal care.

Among the limitations of the survey, due to the sensitive issues of intimate nature, the validity of responses is questioned in the literature 39,40 . The differences by gender observed in this study regarding sexual practices may also be related to the fact that women, when compared to men, tend to underestimate their sexual risk behaviors in surveys 41 . With the purpose of minimizing bias arising from this type of limitation in the 2008 KAP Study, information about sexual practices were self-resported by using a PDA. The self use of computer-assisted self-interviewing methods has been proven to provide accurate information $42,43,44$.

In sum, the results presented herein show greater vulnerability of the female population to unsafe sexual practices. The power of decisionmaking on preventive methods in sexual relationships is generally unfavorable for women and constitutes a major obstacle in implementing strategies for practicing protected sex for the population as a whole. These difficulties must be addressed through interventions that empower women in negotiations to use condoms with their sexual partners or by developing methods that allow greater self-control. Among men, it is necessary to encourage HIV testing for more effective control of the dissemination of the HIV/ AIDS epidemic. Yet, the low use of condoms in situations of extramarital sex among married individuals or those living with a partner has become a problem for both genders and it deserves specific consideration in the development of preventive strategies. 


\section{Resumo}

O objetivo do trabalho foi analisar as diferenças por sexo nas práticas relacionadas à infecção pelo HIV na população brasileira. Inquérito de âmbito nacional foi realizado em 2008, com amostra de 8 mil indivíduos de 15-64 anos. A amostragem foi estratificada por macrorregião geográfica e situação urbano/rural. Utilizou-se modelo de regressão logística para investigar os principais fatores associados às práticas de sexo protegido. Os resultados indicaram que as mulheres têm menor taxa de atividade sexual, iniciam a vida sexual mais tardiamente, têm menos parceiros casuais do que os homens, mas usam menos o preservativo. Por outro lado, a cobertura de teste de HIV é significativamente maior entre as mulheres quando comparadas aos homens. Foram evidenciadas grandes diferenças por sexo nas práticas relacionadas à infecção pelo HIV, sempre com maior vulnerabilidade associada às mulheres, exceto no que diz respeito ao teste de HIV. O baixo uso de preservativo nas situações de infidelidade foi um problema para ambos os sexos e merece consideração específica nas estratégias de prevenção.

Comportamento Sexual; Sorodiagnóstico da AIDS; Infecções por HIV; Características Sexuais

\section{References}

1. Rodrigues-Júnior AL, Castilho EA. A epidemia de AIDS no Brasil, 1991-2000: descrição espaço-temporal. Rev Soc Bras Med Trop 2004; 37:312-7.

2. Barcellos C, Bastos FI. Redes sociais e difusao da AIDS no Brasil. Bol Oficina Sanit Panam 1996; 121:11-24.

3. Szwarcwald CL, Bastos FI, Esteves MAP, Andrade CLT. A disseminação da epidemia da AIDS no Brasil, no período de 1987-1996: uma análise espacial. Cad Saúde Pública 2000; 16 Suppl 1:7-19.

4. Ministério da Saúde. Boletim Epidemiológico AIDST 2008; Ano V, n ${ }^{\circ} .1$.

5. Ministério da Saúde. Plano integrado de enfrentamento à feminização da epidemia de AIDS e outras DST. Brasília: Ministério da Saúde; 2007.

6. Ministério da Saúde. Profissionais do sexo: documento referencial para ações de prevenção das DST e da AIDS. Brasília: Ministério da Saúde; 2002. (Série Manuais, 47).

7. Anderson JE, Stall R. How many people are at risk for HIV in the United States? The need for behavioral surveys of at-risk populations. J Acquir Immune Defic Syndr 2002; 29:104-5.

8. Programa Nacional de DST e AIDS, Secretaria de Vigilância em Saúde, Ministério da Saúde. Pesquisa entre os conscritos do Exército Brasileiro, 1996-2002: retratos do comportamento de risco do jovem brasileiro à infecção pelo HIV. Brasília: Ministério da Saúde; 2002.

\section{Contributors}

A. R. P. Pascom was responsible for the text development, statistical analysis of data and development of tables. C. L. Szwarcwald participated in the text development and article conception.
9. Szwarcwald CL, Carvalho MF, Barbosa Júnior A, Barreira D, Speranza FA, Castilho EA. Temporal trends of HIV-related risk behavior among Brazilian military conscripts, 1997-2002. Clinics 2005; 60:367-74

10. Sociedade Civil Bem-Estar Familiar no Brasil. Pesquisa Nacional sobre Demografia e Saúde: uma análise do nível de conhecimento e comportamentos de vulnerabilização. Rio de Janeiro: Sociedade Civil Bem-Estar Familiar no Brasil; 1997.

11. Berquó E, Barbosa RM, Lima LP; Grupo de Estudos em População, Sexualidade e Aids. Uso do preservativo: tendências entre 1998 e 2005 na população brasileira. Rev Saúde Pública 2008; 42 Suppl 1:7-11.

12. Coordenação Nacional de DST e AIDS. PCAP Pesquisa de Conhecimento, Atitudes e Práticas na População Brasileira 2004. Brasília: Ministério da Saúde; 2006.

13. Bolfarine H, Bussab WO. Elementos de amostragem. São Paulo: Editora Edgard Blucher; 2005.

14. Szwarcwald CL, Damacena GN. Amostras complexas em inquéritos populacionais: planejamento e implicações na análise estatística dos dados. Rev Bras Epidemiol 2008; 11 Suppl 1:S38-45.

15. Hosmer DW, Lemeshow S. Applied logistic regression. 2nd Ed. New York: John Wiley \& Sons; 1989. 
16. Associação Brasileira de Empresas de Pesquisa. Critério de Classificação Econômica Brasil. http:// www.abep.org/codigosguias/Criterio_Brasil_2008. pdf (accessed on 09/Aug/2009).

17. Almeida MC, Aquino EM, Gaffikin L, Magnani RJ. Contraceptive use among adolescents at public schools in Brazil. Rev Saúde Pública 2003; 37: 566-75.

18. Barbosa RM, Koyama MA; Grupo de Estudos em População, Sexualidade e AIDS. Sexual behavior and practices among men and women, Brazil 1998 and 2005. Rev Saúde Pública 2008; 42 Suppl 1: 21-33.

19. Calazans G, Araujo TW, Venturi G, Franca Junior I. Factors associated with condom use among youth aged 15-24 years in Brazil in 2003. AIDS 2005; 19 Suppl 4:S42-50.

20. Gullette DL, Rooker JL, Kennedy RL. Factors associated with sexually transmitted infections in men and women. J Community Health Nurs 2009; 26:121-30.

21. Urassa W, Moshiro C, Chalamilla G, Mhalu F, Sandstrom E. Risky sexual practices among youth attending a sexually transmitted infection clinic in Dar es Salaam, Tanzania. BMC Infect Dis 2008; 8:159.

22. Frank S, Esterhuizen T, Jinabhai CC, Sullivan K, Taylor MS. Risky sexual behaviours of high-school pupils in an era of HIV and AIDS. S Afr Med J 2008; 98:394-8.

23. Martinez-Donate AP, Hovell MF, Blumberg EJ, Zellner JA, Sipan CL, Shillington AM, et al. Gender differences in condom-related behaviors and attitudes among Mexican adolescents living on the U.S.-Mexico border. AIDS Educ Prev 2004; 16: 172-86.

24. Ehrhardt AA, Sawires S, McGovern T, Peacock D, Weston M. Gender, empowerment, and health: what is it? how does it work? J Acquir Immune Defic Syndr 2009; 5 Suppl 3:S96-105

25. Shawky S, Soliman C, Sawires S. Gender and HIV in the Middle East and North Africa: lessons for low prevalence scenarios. J Acquir Immune Defic Syndr 2009; 51 Suppl 3:S73-4.

26. Paiva V, Calazans G, Venturi G, Dias R; Grupo de Estudos em População, Sexualidade e AIDS. Age and condom use at first sexual intercourse of Brazilian adolescents. Rev Saúde Pública 2008; 42 Suppl 1:45-53.

27. Kornreich JL, Hearn KD, Rodriguez G, O'Sullivan LF. Sibling influence, gender roles, and the sexual socialization of urban early adolescent girls. J Sex Res 2003; 40:101-10.

28. Roth J, Krishnan SP, Bunch E. Barriers to condom use: results from a study in Mumbai (Bombay), India. AIDS Educ Prev 2001; 13:65-77.

29. Crosby RA, DiClemente RJ, Wingood GM, Salazar LF, Harrington K, Davies SL, et al. Identification of strategies for promoting condom use: a prospective analysis of high-risk African American female teens. Prev Sci 2003; 4:263-70.

30. Madrigal J, Schifter J, Feldblum PJ. Female condom acceptability among sex workers in Costa Rica. AIDS Educ Prev 1998; 10:105-13.
31. Warren M, Philpott A. Expanding safer sex options: introducing the female condom into national programmes. Reprod Health Matters 2003; 11:130-9.

32. Card JJ, Amarillas A, Conner A, Akers DD, Solomon J, DiClemente RJ. The complete HIV/AIDS teaching kit. New York: Springer Publishing Company; 2008.

33. Al-Tayyib AA, McFarlane M, Kachur R, Rietmeijer CA. Finding sex partners on the internet: what is the risk for sexually transmitted infections? Sex Transm Infect 2009; 85:216-20.

34. Fernández-Dávila P, Zaragoza Lorca K. Internet y riesgo sexual en hombres que tienen sexo con hombres. Gac Sanit 2009; 23:380-7.

35. Zhang D, Bi P, Hiller JE, Lv F. Web-based HIV/AIDS behavioral surveillance among men who have sex with men: potential and challenges. Int J Infect Dis 2008; 12:126-31.

36. Elford J, Bolding G, Davis M, Sherr L, Hart G. Webbased behavioral surveillance among men who have sex with men: a comparison of online and offline samples in London, UK. J Acquir Immune Defic Syndr 2004; 35:421-6.

37. Souza-Jr PR, Szwarcwald CL, Castilho EA. Delay in introducing antiretroviral therapy in patients infected by HIV in Brazil, 2003-2006. Clinics 2007; 62:579-84.

38. Centers for Disease Control and Prevention. Number of persons tested for HIV: United States, 2008. MMWR Morb Mortal Wkly Rep 2008; 57:845-9.

39. Curtis SL, Sutherland EG. Measuring sexual behaviour in the era of HIV/AIDS: the experience of Demographic and Health Surveys and similar enquiries. Sex Transm Infect 2004; 80 Suppl 2:ii22-7.

40. Hawken MP, Melis RD, Ngombo DT, Mandaliya KN, Ng'ang'a LW, Price J, et al. Opportunity for prevention of HIV and sexually transmitted infections in Kenyan youth: results of a population-based survey. J Acquir Immune Defic Syndr 2002 15; 31:529-35.

41. Schroder KE, Carey MP, Vanable PA. Methodological challenges in research on sexual risk behavior: II. Accuracy of self-reports. Ann Behav Med 2003; 26:104-23.

42. Nguyen TQ, Gwynn RC, Kellerman SE, Begier E, Garg RK, Pfeiffer MR, et al. Population prevalence of reported and unreported HIV and related behaviors among the household adult population in New York City, 2004. AIDS 2008; 22:281-7.

43. Simoes AA, Bastos FI, Moreira RI, Lynch KG, Metzger DS. A randomized trial of audio computer and in-person interview to assess HIV risk among drug and alcohol users in Rio de Janeiro, Brazil. J Subst Abuse Treat 2006; 30:237-43

45. Ghanem KG, Hutton HE, Zenilman JM, Zimba R, Erbelding EJ. Audio computer assisted self interview and face to face interview modes in assessing response bias among STD clinic patients. Sex Transm Infect 2005; 81:421-5.

Submitted on 23/Oct/2009

Final version resubmitted on $06 / \mathrm{Feb} / 2010$

Approved on 19/Apr/2010 